\title{
Central Banks' Demand for Foreign Reserves Under Fixed and Floating Exchange Rates
}

\author{
DALLAS S. BATTEN
}

$\mathrm{T}$

HE international monetary system has experienced significant changes during the 1970s. The most dramatic of these has been the transformation from a system of pegged exchange rates to one in which central banks make no institutional commitment to maintain a particular exchange rate. Despite this change, central banks have been unwilling, in general, to allow their exchange rates to be completely market-determined and, consequently, continue to hold foreign reserves. The primary focus of this article is to analyze central banks' demand for foreign reserves in light of this institutional change.

Central banks generally are thought to hold stocks of foreign reserves so their economies can avoid incurring the costs of adjusting to every intemational imbalance that would be transmitted to the domestic economy through changes in exchange rates. In particular, before March 1973, central banks participating in the Bretton Woods Agreement were compelled to hold foreign reserves because they were committed to intervene in foreign currency markets when the value of their currencies moved outside a predetermined range.

It was commonly believed that the demise of the Bretton Woods Agreement and the concomitant greater Hexibility of exchange rates would reduce central banks' intervention in foreign currency markets and, consequently, reduce their demand for foreign reserves. That is, since perhaps the single, most important reason for holding reserves had diminished, central banks would not be expected to hold such large stocks of foreign reserves as they had under the fixed exchange rate system. In spite of this expectation, however, central banks have continued to maintain sizable stocks of reserves since March

The author would like to thank John Bilson, Michael Bordo and Ed Ray for their comments on an earler diaft.
1973. This observation has led researchers to conclude that central banks have not changed appreciably their demand for reserves with the transition from a fixed to a floating exchange rate system. ${ }^{1}$

This conclusion, though potentially accurate, is founded on a framework of analys is in which foreign reserves are considered by central banks as a very special type of asset - one held solely to enable them to intervene in foreign currency markets. However, there is an alternative framework for analyzing central bank behavior that predicts that, even if all countries had adopted a completely cleanfloating exchange rate system in 1973, central banks would have continued to hold a variety of financial assets, some of which would have been classified as foreign reserves under the previous fixed exchange rate system. This article investigates which of these competing frameworks better explains central bank behavior since March 1973.

\section{TW MODELS OP CENTRAL BAN BEA}

To analyze whether or not central bank behavior has changed significantly since the introduction of flexible exchange rates, the demand for reserves based on the intervention motive is compared with an alternative one developed within an assetwchoice

\footnotetext{
1See, for example, Jacob A. Frenkel, "International Reserves: Pegged Exchange Rates and Maxaged Float," in Karl Brumer and Allan H. Meltzer, eds., Public Policies in Open Economies, Carnegie-Rochester Conference Series on Public Policy, supplement to the Journal of Monetary Economics, Volume 9(1978), pp. 111-40; H. Robert Heller and Mohsin S. Kahn, "The Demand for Intemational Reserves Under Fixed and Floating Exchange Rates," Intemational Monetary Find Staff Papers (December 1978), pp. 623-49; Nasser Saidi, "The Square-Root Lalw, Uncertainty and International Reserves Under Altemative Rem gimes,"Joumal of Montary Ecotomics (May 1981), pp. 271-90.
} 
framework. ${ }^{2}$ Only if the former explanation outperforms the latter for the floating period can one conclude that the changes in behavior since 1973 have been relatively minor and inconsequential.

The first model is the standard one based on the derived demand for foreign reserves for purposes of intervening in foreign exchange markets. Since this model has appeared frequently in the literature, its characteristics are only briefly described. ${ }^{3}$ The second model is based on asset-choice behavior and has not been applied, until now, to the analysis of foreign reserve demand. In this model, foreign reserves are treated as one of several assets that appear in a bank's portfolio and are held for the general conduct of monetary policy.

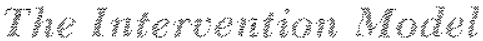

The central bank intervention motive has been thoroughly investigated. Earlier studies typically have employed an optimizing approach in determining the demand for foreign reserves. One procedure is to find the stock of reserves at which the marginal costs of holding them equal the marginal benefits of using them to intervene in foreign currency markets (i.e., the avoidance of costs associated with the domestic economy having to adjust to each external shock). A second procedure is conducted in terms of welfare maximization under uncertainty. In particular, a central bank's demand for foreign reserves is the result of its maximizing a

\footnotetext{
${ }^{2}$ See Russell S. Bover and David Laidler, "A Comment on the Frenkel Paper," in Brumer and Meltzer, eds., Public Policies in Open Economies, pp. 141-43.

${ }^{3}$ Examples of this and similar models inchade Peter B. Clark, "Demand for International Reserves: A Cross-Country Analysis," Canadian Joumal of Economics (November 1970), pp.

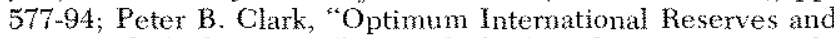
the Speed of Adjustment, foumal of Political Economy March April 1970), pp. 356-76; T.J. Courchere and G. M. Youssef, "The Demand for International Reserves, "Journal of Political Economy (August 1967), pp. 404-13; Jacob A. Frenkel, "The Demand for International Reserves by Developed and LessDeveloped Countries, "Economica (Febtuary 1974), pp. 14-24; Frenkel, "International Reserves: Pegged Exchange Rates and Managed Float"; $H$. Robert Heller, "Optimal International Reserves," Economic Jowmal (June 1966) pp. 296-311; Heller and Khan, "The Denand for International Reserves Under Fixed and Floating Exchange Rates"; F. Steb Hipple, The Disturbance Approach to the Demand for International Reserves, Princeton Studies in Intemational Finance No. 35 (Princeton University Press, 1974); Milton A. Iyoha, "Demand for Intermational Reserves in Less-Developed Countries: A Distributed Lat Specifieation," The Retiet of Economics and Sfatistics (Angust 1976), pp. 351-55; Michael G. Kelly, "The Demand for Intemational Reserves," The American Economic Review (September 1970), pp. 655.67; and Saidi, "The Square-Root Law, Uncertainty and Intemational Reserves."
}

societal welfare function which is a positive function of the expected level of real income and a negative function of its variability. Since the holding of foreign reserves diverts resources away from domestic uses, the larger the stock of reserves, the lower the expected level of real income. However, if no reserves are held, the domestic economy would have to adjust to every external shock, resulting in more real income variability.

Employing the intervention motive within this framework, previous studies have identified four major determinants of reserve demand; the vari ability of international payments and receipts, the propensity to import, the opportunity cost of holding reserves and a scale variable measuring the size of international transactions (usually the value of imports). The variability of receipts and payments measures the likelihood that external disequilibrium will occur, inducing the central bank to intervene in foreign currency markets in order to mitigate the impact of this disequilibrium on domestic markets. The larger the variability of a country's receipts and payments, the more susceptible is that country to external disequilibrium; consequently, the larger is the optimal stock of reserves desired for purposes of intervention.

There are two possible rationales for including the propensity to import as a determinant of reserve demand. First, the average propensity to import can be considered a measure of the degree of openness in an economy, thus indicating the degree to which the economy is vulnerable to an extemal disequilib. rium. A second, alternative rationale stems from the Keynesian model of an open economy in which an external disequilibrium could be corrected, without changing the exchange rate, by a change in output in proportion to the foreign trade multiplier. This output cost of adjustment could be avoided if the central bank used its stock of foreign reserves to finance (or to sterilize) the disequilibrium. Since this output cost is directly related to the size of the foreign trade multiplier, and since this multiplier is inversely related to the marginal propensity to import, the output cost of not holding sufficient reserves necessary to avoid this adjustment and, thus, the central bank's demand for reserves, must also be inversely velated to the marginal propensity to import. Because the marginal propensity to import is difficult to measure, most studies have substituted the average propensity as a proxy. However, if the average propensity to import is employed both as a proxy for the marginal propensity and as a measure of 
openness, the sign of its impact on reserve demand is ambiguous.

Since central banks do not hold an infinite stock of foreign reserves, there must be some cost associated with holding them. Conceptually, from society's point of view, holding foreign reserves represents an allocation of scarce resources away from domestic uses. Presumably, for every dollar invested in its stock of foreign reserves (through its central bank), society foregoes a dollar of domestic capital formation. Consequently, a rate of retum on domestic capital is the appropriate measure of the opportunity cost to society of its central bank's stock of foreign reserves. On the margin, the optimal stock of reserves is that level at which the cost of holding reserves equals the marginal benefits provided by that stock of reserves. Few studies have included explicitly a measure of opportunity cost. Moreover, those that have included it have not found it to be empirically significant. ${ }^{4}$ The hypothesized reason for the overall poor performance of this variable is the strong positive relationship between it and the supply of reserves. In particular, the higher the opportunity cost of holding reserves, the higher also the domestic rate of return on financial capital which motivates capital inflows and, ceteris paribus, increases the supply of reserves. As described below, interest rate differentials are employed as an attempt to circumvent this problem.

Finally, the scale variable and the demand for foreign reserves should be positively related. In fact, if the value of international transactions is used as the scale variable, the elasticity of reserve demand with respect to the value of international transactions should be between 0.5 and $1.0 .^{5}$

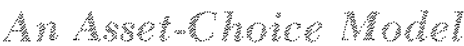

In formulating an asset-choice model of central bank behavior, foreign reserves are treated simply as one type of asset in a central bank's portfolio held to enable the central bank to conduct domestic monetary policy. It is assumed that the primary objective

\footnotetext{
4See, for example, Courchene and Youssef, "The Demand for International Reserves"; Iyoha, "Demand for International Reserves in Less-Developed Countries"; Kelly, "The Demand for International Reserves"; and Said, "The Square-Root Law, Uncertainty, and International Reserves."

s See Ernst Baltensperger, "The Precationary Demand for Reserves," The American Economic Reciew (March 1974) pp. 205-10, and J. H. G. Olivera, "The Square-Root Law of Precantonary Reserves," foumal of Politichl Econemy (Septemberi October 1971), pp. $1095-1104$.
}

of monetary policy is to provide an economic environment conducive to the stable, noninfationary growth of real output. To this end, the central bank affects the level of commercial bank reserves (and, subsequently, the money supply) through activity in government securities and foreign currency markets and by making loans directly to the banking sector. Consequently, to conduct monetary policy adequately, its portfolio should contain at least three assets: foreign reserves, government securities and claims on commercial banks.

A central bank typically confronts two types of economic phenomena - expected and mexpected - to which it makes policy responses. In light of this, the specific modeling of the portfolio decisionmaking process of a central bank involves separating its assets into two categories: committed and uncommitted assets. In response to its anticipations of prospective events, a central bank commits a portion of its portfolio so that it can pursue its monetary policy objective within this "expected" economic environment.

However, since a central bank also is faced with unanticipated economic events to which it may wish to respond, it must hold additional reserves to enable it to respond to these "unexpected" occurrences (or shocks) as well. These "precautionary" reserves may or may not be used for the conduct of monetary policy in any specific period, while the committed portion, is, by definition, fully involved in the monetary control process. Consequently, a central bank is concemed only with the yield (cost) on the potentialy idle, precautionary portion. That is, a central bank's demand for the assets that form the committed component is hypothesized to be insensitive to their relative yields, whereas the composition of the precautionary (or uncommitted) reserve component is hypothesized to be sensitive to changes in relative asset yields.

To formalize this discussion of central bank behavior, assume that a central bank (subject to certain constraints) desires to maximize its "ability" to respond to unanticipated events. It accomplishes this by maximizing the uncommitted portion of its portfolio. ${ }^{6}$ This can be summarized with the fol-

\footnotetext{
A A model assuming a wealth-maxmizing objective of the U.S. Federal Reserve System has been slown to be a better predictor of Fed behavior than the traditional model of the Fed as an automaton reacting only to poltical pressures. See Mark Toma. "Intationary Bias of the Federal Reserve System: A Bureancratic Perspective" tmpublished manuscript (California State University, Northridge, 1981). Consequently, applying a similar assumption to other central hanks is not without precedent.
} 
lowing objective function:

$$
\text { (1) } F\left(x_{1}, \ldots, x_{11}\right)=\prod_{k=1}^{n}\left(x_{k}-\gamma_{k}\right)^{\beta_{k}} \text {, }
$$

where $x_{k} \quad=$ asset k's maturity value at the end of the time period,
$\gamma_{k}=$ the committed or required value of asset $k$,

$x_{k}-y_{k}=$ the uncommitted or precantionary value of asset $k$,

$\beta_{k}=$ asset $k$ 's share of the uncommitted portfolio,

and $\sum_{k=1}^{n} \beta_{k}=1$,

which the central bank maximizes subject to the following balance sheet accounting constraint:

(2) $\mathrm{TA}=\sum_{\mathrm{k}=1}^{\mathrm{I}=1} \mathrm{v}_{\mathrm{k}} \mathrm{x}_{\mathrm{k}}$,

where $\mathrm{v}_{\mathrm{k}}=\frac{1}{1+\mathrm{r}_{\mathrm{k}}}$

$\mathrm{r}_{\mathrm{k}}=$ the yield on asset $\mathrm{k}$ within the period,

TA $=$ the present value of the assets in the portfolio. ${ }^{7}$

The resulting system of asset-demand equations is as follows: 8

(3) $\begin{aligned} \mathrm{x}_{\mathrm{k}} & =\gamma_{\mathrm{k}}+\underset{\mathrm{v}_{\mathrm{k}}}{\beta_{\mathrm{k}}}\left(\mathrm{TA}-\underset{j=1}{\mathrm{n}} \gamma_{\mathrm{j}} \mathrm{v}_{\mathrm{j}}\right) \\ \mathrm{k} & =1, \ldots, \mathrm{n}\end{aligned}$

It is clear from equation 3 that a central bank's demand for each asset in its portfolio has two primary components. The first is the required or committed portion $\left(\gamma_{\mathrm{k}}\right)$, which is determined regardless of yields. The second, or precautionary, component is the

TAll assets are as sumed to mature in one period, bul longer-lived assets cond be included whout a substantive change in the analysis. Also, sinee the issue investigated here is a central bank's allocation of a given portfolio among various assets, the detemination of the size of the portfolio in any fime period ( $\mathrm{TA}_{t}$ ) is not considered. For sone insights into this question, see Toma, "Intlationary Bias of the Federal heserve System."

${ }^{8}$ More formally, the system of demand equations represented by equation 3 is derived by setting up the Lagrangean function and maximizing at with respect to each asset as follows:

(1) $\mathrm{L}=\prod_{\mathrm{k}=1}^{n}\left(\mathrm{x}_{\mathrm{k}}-\gamma_{\mathrm{k}}\right)^{\beta_{\mathrm{k}}}+\lambda\left(\mathrm{TA}-\sum_{\mathrm{k}=1}^{\mathrm{n}} \mathrm{v}_{\mathrm{k}} x_{\mathrm{k}}\right)$ remainder of its balance sheet (TA $-\sum_{j=1}^{n} \gamma_{j} v_{j}$ ),

which the bank allocates to the various assets (in proportions denoted by $\beta_{\mathrm{k}}$ ) according to relative yields in a manner that maximizes its objective function. ${ }^{9}$

(2) $\frac{\partial L}{\partial \mathrm{x}_{j}}=\left(\mathrm{x}_{1}-\gamma_{1}\right)^{\beta_{1}}\left(\mathrm{x}_{2}-\gamma_{2}\right)^{\beta_{2}} \ldots\left(\mathrm{x}_{\mathrm{j}-1}-\gamma_{\mathrm{j}-1}\right)^{\beta_{\mathrm{j}-1}}$

$$
\begin{aligned}
& \left(x_{j+1}-\gamma_{j+1}\right)^{\beta_{j+1}} \ldots\left(x_{n}-\gamma_{n j}\right)^{\beta_{n}} \\
& \beta_{j}\left(x_{j}-\gamma_{j}\right)^{\beta_{j}-1}-\lambda v_{j}=0 \\
= & \beta_{j}\left(x_{j}-\gamma_{j}\right)^{-1} \mathrm{~F}-\lambda v_{j}=0 \text { or }
\end{aligned}
$$

(3) $\frac{F}{\lambda}=\frac{v_{j}}{\beta_{j}}\left(x_{j}-\gamma_{j}\right)$

Solving $\left(3^{\prime}\right)$ for $\beta_{\mathrm{j}}$ yields

(4') $\beta_{j}=\frac{\lambda v_{j}\left(x_{j}-\gamma_{j}\right)}{F}$.

Since $\sum_{k} \beta_{k}=1$,

(5) $\underset{j}{\Sigma} \beta_{\mathrm{j}}=\frac{\lambda}{\mathrm{F}} \underset{\mathrm{j}}{\mathrm{\Sigma}} \mathrm{v}_{\mathrm{j}}\left(\mathrm{x}_{\mathrm{j}}-\gamma_{\mathrm{j}}\right)=1$

$$
\begin{aligned}
& =\frac{\lambda}{F}\left(\underset{j}{\Sigma} v_{j} x_{j}-\sum_{j} v_{j} \gamma_{j}\right) \\
& =\frac{\lambda}{F}\left(T A-\sum_{j} v_{j} \gamma_{j}\right) \text { from }(2) \text { in the text or }
\end{aligned}
$$

(6) $\frac{\mathrm{F}}{\lambda}=\operatorname{TA}-\sum_{j} v_{j} \gamma_{j}=\frac{v_{i}}{\beta_{j}}\left(x_{i}-\gamma_{j}\right) \operatorname{from}\left(3^{\prime}\right)$.

Solving $\left(6^{\prime}\right)$ for $x_{j}$ yields:

$\left(7^{\prime}\right) x_{j}=\gamma_{j}+\frac{\beta_{j}}{v_{j}}\left(\mathrm{TA}-\sum_{j} v_{j} \gamma_{j}\right)$

which is the system repuesenfed by (3) in the text. It can be shown that the own-price elasticity of demand for asset $\mathrm{j}$ is

(8) $\xi_{\mathrm{x}}=-1+\frac{y_{\mathrm{j}}\left(1-\beta_{\mathrm{j}}\right)}{\mathrm{x}_{\mathrm{j}}}$,

and that the Allen partial elasticity of substitution between assets $i$ and $j$ is

(9) $\delta_{i j}=\left(\frac{x_{1}-\gamma_{i}}{x_{i}}\right)\left(\frac{x_{i}-\gamma_{j}}{x_{i}}\right) \sum_{k=1}^{n} \beta_{k}\left(\frac{x_{k}}{x_{k}-\gamma_{k}}\right)$

For $\left(x_{k}-\gamma_{k}\right)>0$, all assets are Hicksian substitutes.

${ }^{9} T$ he value of $y_{k}$ is determined by those variables that influence each comtry s monetary policy decisions (e.g., economic activ ity, unemployment, inflation). Cortainly, interest rates may be included in this group of determinants. However, since $\gamma_{k}$ is estimated, the hypothesized interest insensitivity of a portion of a central bank's portfolio can be easily ested. Specifically, if $\hat{\gamma}_{k}$ is statistically significant, the hypothesis that a central bank holds a portion of its portfolio for reasons other than relative yields cannot be rejected. Also, the hypothesis that any part of the portfolio is sensitive to changes in interest rates can be tested by testing the statistical significance of $\hat{\beta}_{k}$. 


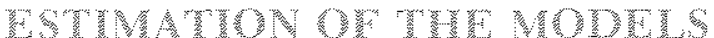

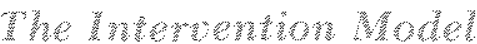

The functional form of central bank demand for foreign reserves for the purpose of exchange market intervention is a familiar one: ${ }^{10}$

(4) $\ln R_{\mathrm{it}}=\mathrm{a}_{0}+\mathrm{a}_{1} \ln \mathrm{M}_{\mathrm{it}}+\mathrm{a}_{2} \ln \mathrm{m}_{\mathrm{if}}+\mathrm{a}_{3} \ln \sigma_{\mathrm{i}}$

$$
+a_{4} \ln \mathrm{r}_{\mathrm{it}}+\mathrm{H}_{\mathrm{it}} \text {, }
$$

where $\mathbf{R}_{\text {it }}=$ the sum of country i's holdings of gold, convertible foreign exchange, SDRs and reserve position in the $\mathrm{IMF}$ at the end of time period $t$,

$\mathbf{M}_{\mathrm{it}}=$ imports of $\mathrm{i}$ during $\mathrm{t}$,

$m_{i t}=i$ 's average propensity to import during $\mathrm{t}\left(\mathrm{M}_{\mathrm{if}} / \mathrm{GDP}_{\mathrm{it}}\right)$,

$\sigma_{i t}=$ the trend-adjusted variance of i's stock of foreign reserves in $t$,

$\mathrm{r}_{\mathrm{if}}=\mathrm{i}^{\prime}$ s opportunity cost of holding foreign reserves during t,

$\mathrm{u}_{\mathrm{it}}=$ errot term.

(All variables denominated in domestic currency units are converted into U.S. dollars using the end-of-period exchange rate.)

The use of imports as a scale variable and the average propensity to import as an indicator of openness have been discussed above. The trend-adjusted variance of country i's stock of foreign reserves is a proxy for the variability of international receipts and expenditures. It is calculated using a method similar to Frenkel's. ${ }^{11}$

The measure of opportunity cost employed is the ratio of the discount rate in each country to the threemonth Eurodollar deposit rate. For a given portfolio of assets, the discount rate represents a measure of the foregone earnings of central banks as a result of holding assets in the form of foreign reserves; the three-month Eurodollar deposit rate is a measure of the income eamed from invested foreign reserves.

\footnotetext{
"See, for example, Frenkel, "International Reserves"; and Heller and Kun, "The Denand for International Reserves Under Fixed and Floating Exchange Rates."

${ }^{11}$ Frenkel, "Intemational Reserves," p. 136. Our measure of variability is actually Frenkel's divided by the number of degrees of freedom (14 in this case); i.e.,$$
\sigma_{\mathrm{il}}=\sum_{\mathrm{m}=\mathrm{t}-15}^{\mathrm{t}-1}\left(\mathrm{R}_{\mathrm{nm}}-\mathrm{R}_{\mathrm{EmL1}}-\eta_{\mathrm{irm}}\right)^{2} / 14 \text {, }
$$

where $\eta_{m}$ is the slope of a linear time-trend equation estimated over the period $t-15$ to $t-1$.
The rationale for this is that central banks hold most of their foreign reserves in the form of U.S. dollars. Instead of holding idle balances of dollars, central banks typically invest their reserves in some shortterm asset in order to maintain a relatively high degree of liquidity; hence, the ratio (or log difference) measures the net foregone yield. Consequently, an appropriate yield on invested foreign reserves is a short-term interest rate on dollar denominated assets. ${ }^{12}$

The sample employed consists of seven coun tries for the time period $\mathrm{V} / 1964$ to IV/1979.13 The countries included are Denmark, France, West Germany, Japan, the Netherlands, Norway and Sweden. The United States is not included because it is considered to be the primary supplier of foreign reserves. The data set consists of a pooling of crosssection and time-series observations.

The possibilities that country-specific variation may be present and that a lagged adjustment process may exist are provided for in the following assumed autoregressive error structure:

(5) $\mathrm{u}_{\mathrm{it}}=\rho_{\mathrm{i}} \mathrm{u}_{\mathrm{it}-\mathrm{I}}+\epsilon_{\mathrm{it}}$

where $\rho_{\mathrm{k}} \quad \approx$ autocorrelation parameter for country $\mathrm{i}$,

$\epsilon_{\mathrm{it}}=$ white noise random errot.

Including a separate autocorrelation parameter for each country captures the country-specific variation

The discount rate is employed because, even though it is not market-determined, its movement closely parallels market rates in the countries in the sample. Also, since most of the central banks studied use interest rates as a mechanism of monetary control, the discount rate reflects conditions in the respective credit markets. Govermment securities markets are not sufficiently developed in all of the countries to be able to use an interest rate from that market. The Eurodollar deposit rate is used as the yield on foreign reserve stocks even though other currencies are held as foreign reserves and ever though some central banks have refrained generally from mosting in the Eutodollar manket directly. The justifications for this are: (a) the U.S. dollar is still the major seserve currency, comprising 66 to 75 percent of the foreign reserves held by central banks, (b) some central barks do invest directly in the Eurodollar natarket while others invest indirectly using the Bank for International Settlements as an intemediary and (c) the major al temative to the Eurodollar market is the market for U.S. Treasury bills. However, since the three-month Eurodollar rate and the threemonth Treasury bill rate move very closely together, they yield virtually identical results when enploved individually in the estimation of both the intervention and the asset-choice models. Finally, the ratio has been criticized as simply a proxy tor the forward discount or premium on the currencies included. However, when the covered ratio is substituted for the uncovered one, no significant qualitative changes ocenr.

13.The sample period extends to T/1980 for Japan, West Cermany and the Netherlands. Gross domestic product data were not avalable for the other countries in the sample for this extented period. 
Table 1

Estimation of Intervention Model

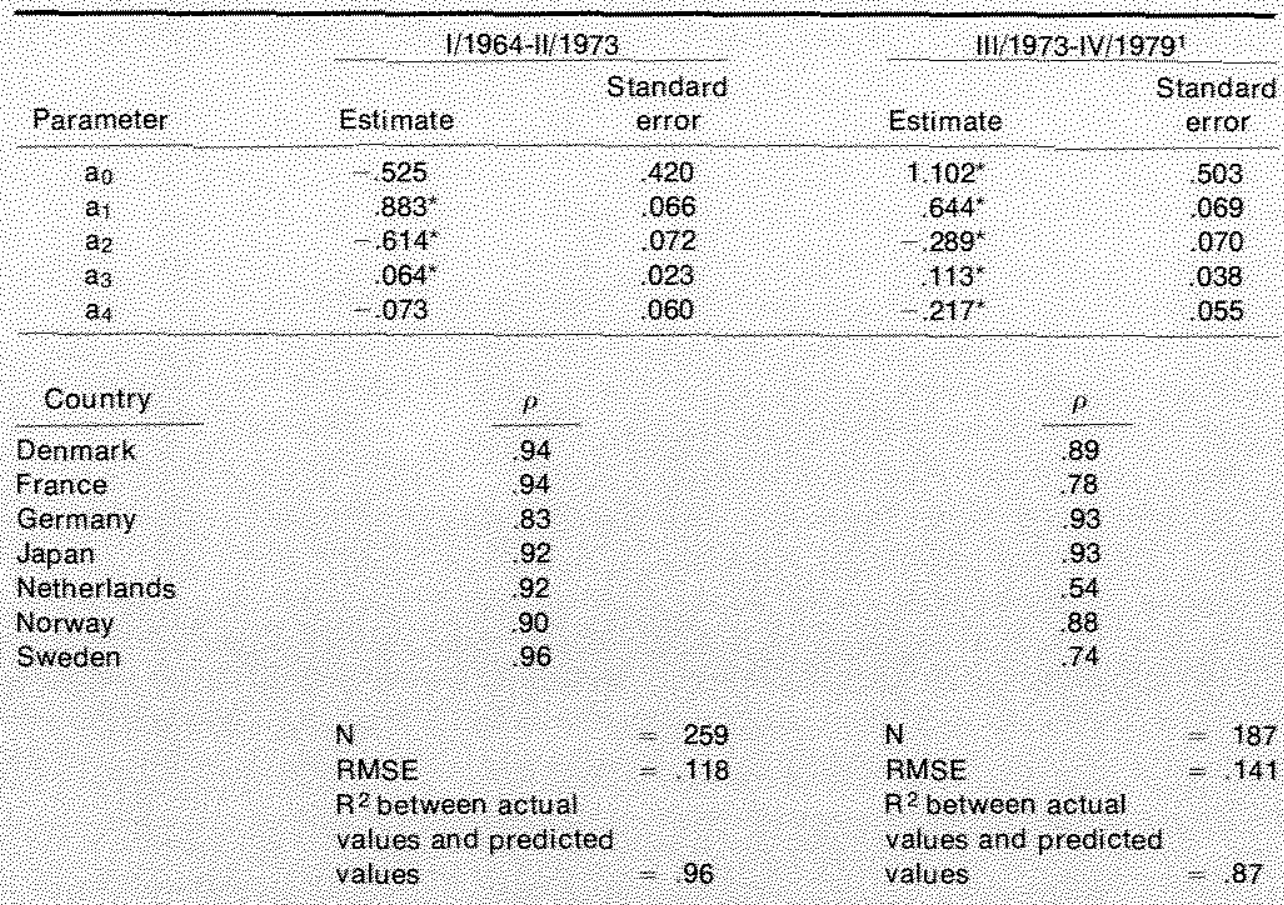

The sample period extends 10 W1980 or Japan. West Germany and the Netherlands

S Signilicently different tron zero at the 5 percent level.

and also provides a means of introducing dynamic behavior into the model. ${ }^{14}$

Finally, the date of the switch from fixed to floating exchange rates must be identified. Since the data are pooled, it is extremely difficult to identify the break point as oecurring at a specific point in time. It is likely the switch oecurred over different intervals for each country analyzed. ${ }^{15}$ Experimentation with various break points around the March 1973 collapse of the Smithsonian Agreement yielded no single quarter as the most likely break point for all of the countries in the sample. Consequently, the break is simply assumed to coincide with the actual failure of

\footnotetext{
${ }^{14}$ For further explanation, see John $F$. O. Bilson and Jacob $A$ Frenkel, "Dynamic Adjustment and the Demand for Intermattional Reserves," NBER Working Paper No. 407 (November 1979), pp. 1-t; and Heller and Khan, "The Demand for Infernationa Reserves Under Fixed and Floating Exchange Rates," p. 631. As pointed out by Heller and Khan, when equation 5 is substituted into equation 4 , the result is observationally equiv. alent to an adaptive-expectations or an error-leaming process.

"5This is supported by Frenkel, "International Reserves," pp. 122-25; and Said, "The Squarem Root Law, Uncertainty and Intemational Reserves," pp. $280-83$
}

the Smithsonian Agreement, that is, between the second and third quarters of $1973 .{ }^{16}$

The results obtained from estimating the solution of equations 4 and 5 over the two time periods indicated above are reported in table 1 . Several differences in the estimated relationships for the two periods are apparent. First, the import elasticity $\left(a_{1}\right)$ in the fixed exchange rate period is significantly larger than that in the floating rate period. In fact, the importelasticity in the fixed period is not statistically different from one, which indicates that central bank holdings of foreign reserves do not exhibit economies of scale during that period. Second, the magnitude of the response to changes in variability $\left(a_{3}\right)$ is

\footnotetext{
16This choice is geremally supported by Frenkel, "International Reserves," pp. 12425 , and by Heller and Khan, "The Demand for Intemational Reserves Under Fixed and Floating Exchange Rates," pp. 637-39. The selection of the break point is also constrained by the necessity to choose the same break point for each model so that the performance can be compared over identical sample periods. Also, for each model, the bypothesis that the estmated parameters betore this point are equal to those after this point is rejected at the 5 percent confidence level.
} 
larger under floating than under fixed rates. This is somewhat paradoxical since one might expect that the increased exchange rate flexibility during the floating mate period would serve as a buffer and, consequently, reduce central banks' response to changes in variability. ${ }^{17}$

Third, the sensitivity of central banks' reserve holdings to interest rate changes under fixed rates $\left(a_{4}\right)$ is insignificant, a result similar to that of other studies. ${ }^{18}$ Altematively, under floating rates, central banks are found to respond in a significant and conceptually consistent manner to changes in interest rates. When compared with those of previous studies, these results suggest that an interest rate differential is a better measure of the opportmity cost of holding reserves. Finally, a comparison of the intercepts $\left(a_{0}\right)$ suggest that central banks are holding larger stocks of foreign reserves, on average, in the floating rate period than they did in the fixed rate period, indicating that they have actually added to their stocks during the floating period.

\section{等}

To estimate the system of asset-demand equations represented by equation 3 , it was assumed that normally distributed random errors enter additively with zero mean and constant variance. As a result of introducing a random component in this manner, the sum of the error terms across all equations in the system must equal zero if the system is to be consistent. ${ }^{19}$ This restriction on the error structure, by introducing linear dependence across equations, has at least two important implications for estimation. First, single-equation estimating techniques are inappropriate. Efficient estimation requires the use of a system technique. Second, the covariance matrix of the entire system is singular. Because of this, at full-

\footnotetext{
17Frenkel "Intenational Reserves" p. 120, also obtained this result; bowever, Sadi, "The Square-Root Law, Uncertainty and Intemational Reserves," p. 285, found smaller responses to changes in variability in the foating-tate period.

1 See footmote 4 .

${ }^{19}$ for the system of asset-demand equations represented by equation 3 to be consistent, the value of the estimated portfolio mist equal the value of the actual portfolio. This condition implies that the error terms acooss all n asset-denand equations must sam to zero. That is, the eror terms across equations are linearly dependent and thus, by definition, correlated. It could also be argued that, for this analysis, the demands for assets are cor related regardess of the consistency condition. In particular, if the impace of foreign exchange maket intervention upon the domestic money supply is sterilized (e.g., through an offsetting sale or purchase of government securities), then foreign exchange holdings and govermment securty holdings are necessarily negatively conrelated.
}

information technique cannot be employed on the entire system of $n$ asset-demand equations simultaneously because the inversion of this covariance matrix is required during the estimation process. Consequently, only n-l equations can be estimated simultaneously. ${ }^{20}$

The countries and time periods employed here are identical to those used in estimating the intervention model. The assets of the central banks of these countries are aggregated into three categories: foreign reserves, claims on government and claims on commercial banks. The interest rates used for these asset groups are the three-month Eurodollar deposit rate (for foreign reserves), short-term government bond yield in country $i$ (for clams on government) and the discount rate in i for clains on commercial banks). The three-month Eurodollar rate is used here for the same reason it was used in the estimation of the intervention model. Also, a dynamic specification is employed to capture lagged adjustment of the committed parameters $\left(\gamma_{\mathrm{k}}\right)$ by allowing them to vary over time. This dynamic feature is introduced into the system by assuming that the committed level of each asset is a function of the total holding of that asset during the previous time period as follows:

(6) $\gamma_{\mathrm{kt}}=\theta_{\mathrm{k}} \mathrm{x}_{\mathrm{kt} \cdot \mathrm{x}}$,

with $0 \leqslant \theta_{k} \leqslant 1$ for all $\mathrm{k}$. The parameter $\theta_{\mathrm{k}}$ reflects a proportional relationship between the committed level of asset $k$ in the current period to the total holding of that asset in the preceding period. Finaly, the date of the switch from fixed to floating exchange rates is the same as in estimating the intervention model.

Substituting equation 6 into equation 3 and recognizing that $n=3$ in this case, the resulting system of assetwemand equations is as follows:

$$
\begin{aligned}
& \text { (7.1) } x_{1 i t}=\theta_{1} x_{1 j-1}+\frac{\beta_{1}}{v_{\text {lit }}}\left(T A_{i t}-\sum_{j=1}^{3} \theta_{j} x_{j i t .1} v_{j i t}\right)+u_{1 i t}
\end{aligned}
$$

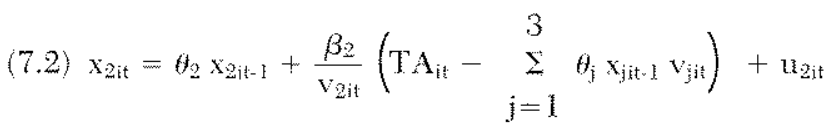

$$
\begin{aligned}
& (7.3) \mathrm{x}_{3 \mathrm{it}}=\theta_{3} \mathrm{x}_{3 \mathrm{it}-1}+\frac{\beta_{3}}{\mathrm{v}_{3 \mathrm{it}}}\left(\mathrm{TA_{it }}-\sum_{j=1}^{3} \theta_{\mathrm{i}} \mathrm{x}_{\mathrm{itt}-1} \mathrm{v}_{\mathrm{jit}}\right)+\mathrm{u}_{3 \mathrm{it}}
\end{aligned}
$$

${ }^{20}$ Robert A. Pollak and Terence J. Wales, "Estimation of the Linear Expenditure System," Econometrica (October 1969), pp. $611-28$. They prove that if a full-information, naximumlikelhood estimation procedure is employed, the estimated parameters are imvariant to whichever n-1 equations are included. 


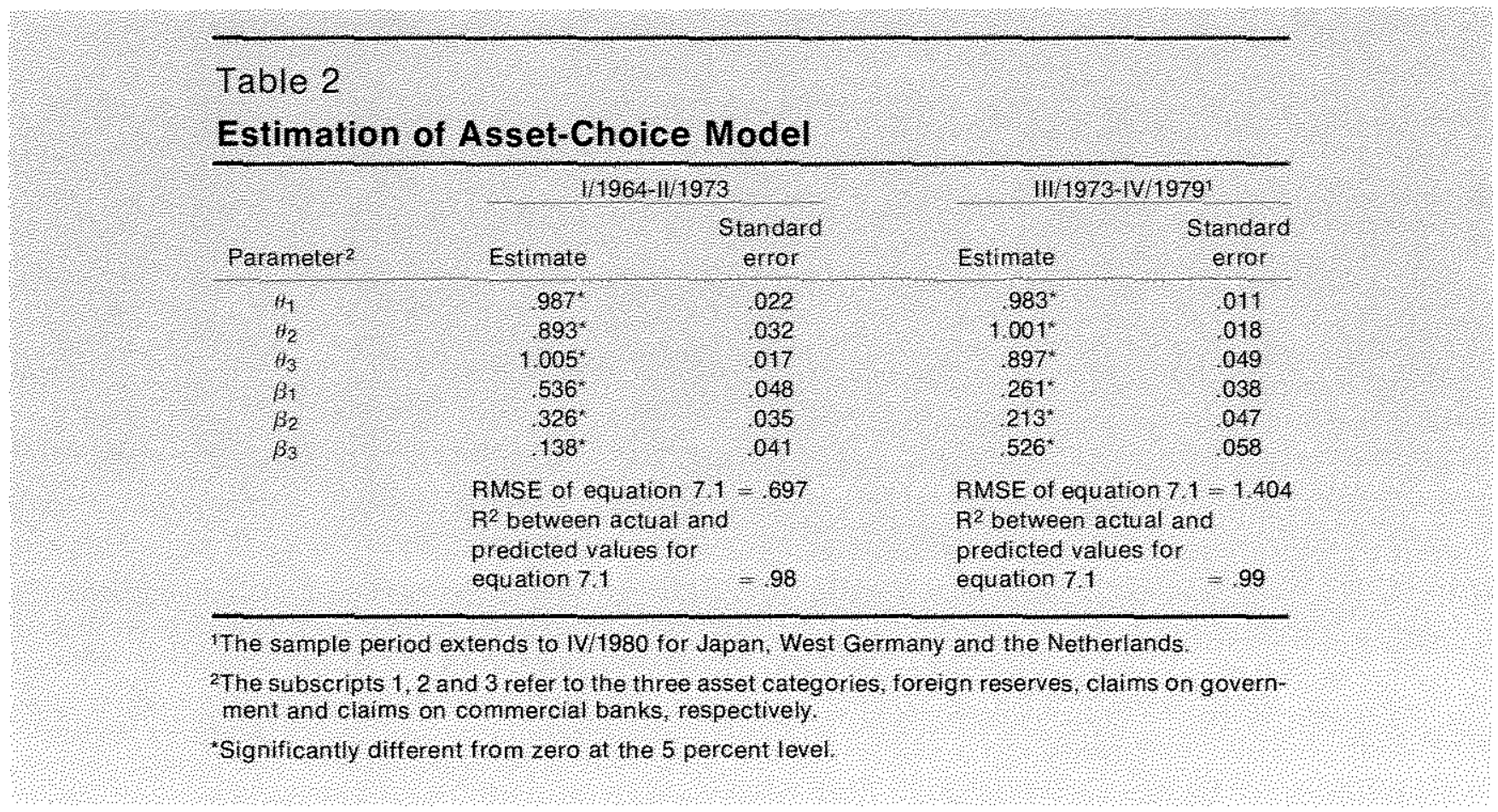

where $\mathrm{x}_{\mathrm{ijt}}=$ the value of country i's holding of asset $j$ at the end of time period $t$,

$$
v_{\mathrm{jt}}=\frac{1}{1+r_{\mathrm{jit}}},
$$

$r_{\mathrm{jit}}=$ the vield on asset $\mathrm{j}$ in country $\mathrm{i}$ from begimning to end of time period $t$,

$\mathrm{TA}_{\mathrm{it}}=$ the value of i's portfolio at begiming of period $t$,

$1_{\text {iit }}=$ error term.

Table 2 presents the results of estimating the above system omitting equation $7.3 .^{21}$ A full-information, maximum-likelihood technique is used to obtain efficient estimates.

All parameter estimates are statistically significant and within conceptually acceptable ranges of values. As before, differences between time periods, but also across assets, are readily apparent. In particular, the estimated committed parameter for foreign reserves $\left(\hat{\theta}_{1}\right)$ is relatively constant across time periods, indicating that central banks have not altered the committed portion of their foreign reserves in the move from fixed to floating exchange rates. On the

\footnotetext{
21Exept for $\beta_{3}$ and its varance, all patrmeters and their variances are estimated directy. Since $\Sigma \beta_{k}=1, \hat{\beta}_{3}=1-\hat{\beta}_{1}-\hat{\beta}_{2}$ and $\mathrm{k}$

$\operatorname{Var}\left(\hat{\beta}_{3}\right)=\operatorname{Var}\left(\hat{\beta}_{\mathrm{f}}\right)+\operatorname{Var}\left(\hat{\beta}_{0}\right)+2 \operatorname{Cov}\left(\hat{\beta}_{1}, \hat{\beta}_{0}\right)$. The same results as those reported were obtained when either equation 7.1 or 7.2 (instead of 7.3 ) was deleted.
}

other hand, the estimated committed parameters for claims on government $\left(\hat{\theta}_{2}\right)$ and for claims on commercial banks $\left(\hat{\theta}_{3}\right)$ have changed significantly with the change in regimes. ${ }^{22}$ Furthermore, the percentage of their discretionary portfolio that central banks held in the form of foreign reserves $\left(\hat{\beta}_{1}\right)$ fell significantly from the fixed to the floating period. The sensitivity of the demand for foreign reserves to changes in interest rates (as measured by the absolute value of the price elasticity of demand) also fell from .563 in the fixed rate period to .289 in the floating rate period. Nonetheless, the fact that this percentage is statistically significant in both periods indicates that reserve holdings are at least partially sensitive to changes in interest rates.

Taken together, the changes in $\hat{\theta}_{1}$ and $\hat{\beta}_{1}$ over the two periods shed some light on why Heller and Khan consistently overpredict central bank demand for foreign reserves during the floating period. ${ }^{23}$ In their model, central banks hold foreign reserves solely to intervene in foreign exchange markets. Alternatively, in the asset-choice model, intervention is simply one of several motives (where the committed parameter measures the demand for reserves for

${ }^{22}$ Even though $\hat{\theta}_{3}$ in the fixed period and $\hat{\theta}_{2}$ in the floating period are greater than $l$ (the coneptual limit of each), neither is significantly greater than 1 in a statistical sense.

${ }^{23}$ Heller and Khan, "The Demand for Intemational Reserves Under Fixed and Floating Exehange Rates;" pp. 639-43. 


\section{Table 3}

\section{Partial Elasticities of Substitution}

\begin{tabular}{|c|c|c|}
\hline Assets & 11964111973 & $1111973 / \mathrm{V} / 1979$ \\
\hline $\begin{array}{l}\text { forelgneserves } \\
\text { and clans } \\
\text { ongovernment }\end{array}$ & 116 & 028 \\
\hline $\begin{array}{l}\text { Foreign reserves } \\
\text { and claims on } \\
\text { commercial banks }\end{array}$ & 031 & 076 \\
\hline $\begin{array}{l}\text { Clans on govennent } \\
\text { and clams on } \\
\text { conmerclal banks }\end{array}$ & 066 & 094 \\
\hline
\end{tabular}

The sample period extends lo W/1980 10 lapan, West Germany and the Netherlands

purposes of intervention).$^{24}$ Even though this relationship appears to be relatively stable across time (in the asset-choice model), overlooking the significant decline in the percentage of the precautionary portfolio held in the form of foreign reserves by basing predictions on a intervention model should lead to an overprediction of reserve demand, ceteris paribus.

One final question remains to be answered: Are the assets in central banks' portfolios close substitutes for each other? To answer this question, partial elasticities of substitution are calculated for each of the asset pairs over each time period. Since these elasticities are functions, inter alia, of the committed and uncommitted levels of each asset, the elasticities reported are evaluated using the mean holdings of the relevant assets (table 3). Given the relatively high estimated values of the committed parameters, it is not too surprising to find that none of the assets are close substitutes.

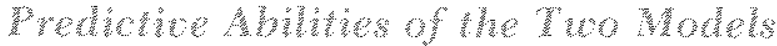

The ultimate test of a structural model is how well it predicts behavior. This section compares the predictive abilities of the two models described above.

\footnotetext{
${ }^{24}$ One may infer that, since the assetwoluce model does not explicitly contain explanatory variables that represent the intervention motive, it is fundamentally misspecified. lowever the estimation of the assetrchoice model clearly indicates that the foreign reserve demands of central banks are sensitive to yields on other assets in their portfolio. Since the intervention model ignores these explanatory variables, it is also funditmentally misspecified. Consequently, future research should be directed at combining the features of both of these models to specify correctly a central bank's demand for foreign reserves.
}

Table 4

\section{Residual-Variance Estimates}

\begin{tabular}{|c|c|c|}
\hline & $1 / 19641 / 1973$ & 111973 v1999? \\
\hline \multicolumn{3}{|c|}{ Intervention model } \\
\hline le evel & 788 & 4577 \\
\hline Log level & 0139 & 0199 \\
\hline \multicolumn{3}{|c|}{ Asset choice nodel } \\
\hline level & 486 & 1970 \\
\hline log evel & 0144 & 0167 \\
\hline
\end{tabular}

The sample per od extends 10 W/980 for Japan West Germany and the Nefterlands.

Two methods of comparison are employed: The first is the residual-variance criterion developed by Theil. ${ }^{25}$ The use of the residual-variance criterion involves calculating a residual-variance estimate (error sum of squares divided by degrees of freedom) for each model and selecting the model with the smallest residual variance. ${ }^{26}$ Since the intervention model is estimated in log-level form and the assetchoice model is not, the residual-variance estimates from the two models are not directly comparable. To make these estimates comparable, either the residuals of the estimated intervention model have to be transformed from logarithms to levels or the residuals of the estimated asset-choice model have to be transformed from levels to logarithms. ${ }^{27}$ Table 4 presents the results of both of these transformations. Except for the logarithmic specification estimated over the fixed rate period, the asset-choice model appears to outperform the intervention model.

These results, however, must be qualified. The residual-variance method presupposes that one of the specifications is the correct one, a somewhat presumptuous supposition. Also, in this case the two

\footnotetext{
${ }^{25}$ Henri Theil, Principles of Econometris (Jom Wiley and Sons, Inc., 1971$)$, pp. 543-45, 553-54.

afr The selection of the specification with the smallest residual variance is justified by the following proposition if the cortect specification has uncorrelated disturbances with zero mean and constant variance and if the explanatory variables ate nonstochastic, the residal-variance estimator of the eorrect specification has an expectation that is never larger than that of an incortert specification. See Theil, Principles of Eromometricis, $p, \$ 43$

2This tratsformation is aceomplished by converting the actual and the predicted values from the level (logarihmic) specifcation into logarithms (anti-logs), calculating the sum of squared devations of the predicted value from the actual, then adjust ing for degrees of freedom.
} 
models compared are non-nested; that is, the models have separate sets of explanatory variables such that one model cannot be obtained from the other. Consequently, the conventional use of summary statistics and F-tests to discriminate among altematives can be misleading and even inappropriate. ${ }^{28}$

The second method is an extension of the Cox test developed by Pesaran and Deaton. ${ }^{29}$ This procedure for testing non-nested hypotheses is not subject to either of the above qualifications necessary for interpreting the results of the residual-variance method. In particular, Pesaran and Deaton's procedure does not employ a single maintained (null) hypothesis. (No model is considered a priori to be the correct one.) The alternative models are analyzed one at a time. One by one, each is assumed to be the correct one.) The alternative models are analyzed one at a time. One by one, each is assumed to be the correct model (null hypothesis); the altemative has been observed. The notion of absolute goodness of fit plays no role in this procedure. In fact, the possibility exists that all competing models may be rejected. This is not the case for conventional testing procedures. ${ }^{30}$

The test statistics calculated with the intervention model and equation 7.1 of the asset-choice model, respectively, as the null hypothesis are reported in table 5. ${ }^{31}$ Under the null hypothesis, this test statistic is asymptotically distributed as a normal random variable with zero mean and unit variance. The ra.

28See M. H. Pesaran, "On the General Problem of Model Selection,"The Retiew of Economic Studies (April 1974), pp. 153-71.

${ }^{20}$ D. R. Cox, "Tests of Separate Families of Hypotheses," in Proceedings of the Fourth Berkeley Sympositam on Mathematical Statistics and Probability University of California Press, 1961), pp. 105-123; M. H. Pestan and A. S. Deaton, "Testing Non-Nested Nonlinear Regression Models," Econometrica (May 1978), pp. 677-94

${ }^{30}$ A necessary condition for the use of this test is that both models explain the same dependent variable. In this case, the first equation of the asset-choice model explains the quantity of reserves denanded while the intervention nodel explains the logarithm of the quantity of reserves demanded. Consequently, to perform the Cox test, the anti-log of the intervention model (i.e., a non-linear, Cobb-Donglas-type function) is estimated using a maximum-likelihood procedure. The resulting predicted values and estimated parameters are essentially identical to those obtained from a least-squares estimation of the loglinear functional form.

31. The test statistic (C) is defined as:

$$
\begin{aligned}
& C=\frac{T_{0}}{\left.\sqrt{\operatorname{Var}\left(T_{0}\right.}\right)} \\
& \text { where } T_{0}=\frac{T}{2} \operatorname{In} \frac{\hat{\sigma}_{A}^{2}}{\hat{\sigma}_{0}^{2}+\frac{1}{T}\left[f\left(\hat{\phi}_{0}\right)-g\left(\hat{\phi}_{M 0}\right)\right]\left[f\left(\hat{\phi}_{0}-g\left(\hat{\phi}_{A 0}\right)\right]\right.},
\end{aligned}
$$

\section{Table 5}

\section{Statistics for Testing Hypotheses Involving Non-Nested Models}

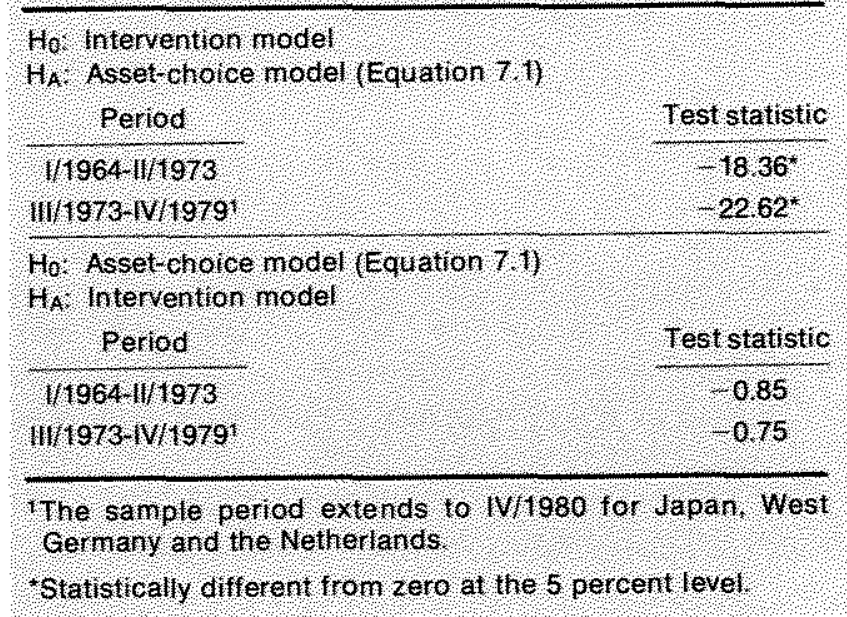

sults are unambiguous. When confronted with the -data and the asset-choice model as an alternative, the intervention model must be rejected. Alternatively, the asset-choice model cannot be rejected. This conclusion is invariant across sample periods. While the rejection of the intervention model for the floating rate period is not unexpected, it is certainly interesting that this model is also rejected for the fixed rate period. This result confirms that the assetchoice model provides a more general explanation of central banks' demand for reserves than does the intervention model.

\section{SUMMART AND CONCLUSTON}

The purpose of this article has been to compare central bank behavior before and after the movement to floating exchange rates within the framework of two altemative models of a central bank's demand for foreign reserves. In the first model,

$$
\begin{aligned}
& \mathrm{T} \quad=\text { sample size, } \\
& \hat{\sigma}_{0}^{2} \quad=\text { estimated variance of the model under } \\
& \hat{\sigma}_{\mathrm{A}}^{2} \quad=\begin{array}{l}
\mathrm{H}_{0,} \\
=\text { estimated variance of the model under }
\end{array} \\
& \mathrm{H}_{\mathrm{A}} \\
& f\left(\hat{\phi}_{0}\right)-g\left(\hat{\phi}_{A 0}\right)=\text { the residuals from an auxiliary esti- }
\end{aligned}
$$


foreign reserves are treated as a special type of asset, one demanded solely to enable a central bank to intervene in foreign currency markets. The second model considers foreign reserves to be the same as and also to be held for the same reasons as - any other asset within a central bank's portfolio.

The estimation of the asset-choice model as an alternative to the intervention model yielded several interesting results. First, a central bank's demand for foreign reserves is sensitive to relative changes in the yields of the assets in the portfolio. Second, central banks consider foreign reserves as substitutes to other assets in their portfolio. Third, the decrease in the percentage of the uncommitted portfolio composed of foreign reserves is identified as a possible reason for the usual overprediction of reserve demand by the intervention model in the floating rate period. Finally, and most importantly, the asset-choice model consistently outperforms the intervention model.

Since the testing procedure employed could lead to the rejection of both models, the fact that the asset-choice model cannot be rejected in either sample period is an extremely robust result. The implication is simply that, regardless of exchange rate regime, central banks hold foreign reserves for a wide variety of purposes - not just for intervention in foreign exchange markets. Consequently, the investigation of whether or not central banks' general behavior has changed with the movement to a system of floating exchange rates within the framework of the intervention model appears to be misdirected. Investigation should focus on the arguments, instead of the parameters, within the demand function.

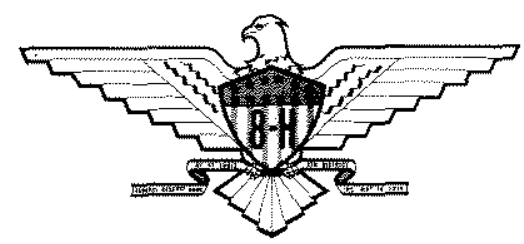

